\title{
Differential Expression of Long Non-Coding RNAs and Their Role in Rodent Neuropathic Pain Models
}

\author{
Songchao $\mathrm{Xu}$ \\ He Dong \\ Yang Zhao \\ Wei Feng
}

Department of Anesthesiology, Affiliated Hospital of Qingdao University, Qingdao University, Qingdao, People's Republic of China
Correspondence: Wei Feng Department of Anesthesiology, Affiliated Hospital of Qingdao University, No. 16, Jiangsu Road, Qingdao, 266003, Shandong Province, People's Republic of China Email fengweisdqd@I26.com

Yang Zhao

Department of Anesthesiology, Affiliated Hospital of Qingdao University, No. 1677, Wutaishan Road, Qingdao, 266555,

Shandong Province, People's Republic of China

Email zhaoy1979@163.com

\begin{abstract}
Neuropathic pain, which is accompanied by an unpleasant sensation, affects the patient's quality of life severely. Considering the complexity of the neuropathic pain, there are huge unmet medical needs for it while current effective therapeutics remain far from satisfactory. Accordingly, exploration of mechanisms of neuropathic pain could provide new therapeutic insights. While numerous researches have pointed out the contribution of sensory neuron-immune cell interactions, other mechanisms of action, such as long non-coding RNAs (IncRNAs), also could contribute to the neuropathic pain observed in vivo. LncRNAs have more than 200 nucleotides and were originally considered as transcriptional byproducts. However, recent studies have suggested that lncRNAs played a significant role in gene regulation and disease pathogenesis. A substantial number of long non-coding RNAs were expressed differentially in neuropathic pain models. Besides, therapies targeting specific lncRNAs can significantly ameliorate the development of neuropathic pain, which reveals the contribution of lncRNAs in the generation and maintenance of neuropathic pain and provides a new therapeutic strategy. The primary purpose of this review is to introduce recent studies of lncRNAs on different neuropathic pain models.
\end{abstract}

Keywords: neuropathic pain, long non-coding RNAs, pain model, treatment, microarray analysis

\section{Introduction}

\section{Overview of Neuropathic Pain}

Pain is a common disease in clinical practice, which has important implications for the human body. Pain perception has evolved as a warning role to respond to organismic danger and tissue damage in a timely manner, then it presents a protective effect by generating related danger signals. ${ }^{1}$ Patients are deeply troubled by the continuous generation of pain signals and the dysfunction of the nervous system. As generally known, neuropathic Pain is a common chronic pain in clinical practice. It is generally caused by the dysfunction of somatosensory neurons in the central or peripheral nervous systems. ${ }^{2}$ Recently, neuropathic pain was redefined as "pain initiated or caused by a primary lesion or dysfunction in the nervous system" by the International Association for the Study of Pain (IASP). ${ }^{3}$ The primary diseases include neurological damage caused by cancer, diabetes, infection, autoimmune diseases, chemotherapy, or trauma. ${ }^{4}$ These conditions usually lead to chronic pain syndrome, manifesting as spontaneous pain, hyperalgesia and allodynia. In addition, chronic pain has been 
shown to cause sleep disturbances, mental illnesses and difficulty in concentrating. ${ }^{5}$ Nearly $8 \%$ of the world's people suffer from chronic pain, which seriously affects the quality of life. $^{6}$

The primary causes for those symptoms of chronic pain include alteration of ion channels (such as calcium and sodium channels) in neurons, ${ }^{7,8}$ activation of immune cells (like microglia, macrophage and $\mathrm{CD} 4+\mathrm{T}$ cell et al) and systemic inflammatory imbalance. ${ }^{1,9,10}$ These results ultimately lead to imbalance between the ascending pain pathways and the descending inhibitory pathway. In sensory transduction, dorsal root ganglion (DRG) is the gathering place of the somatosensory primary afferent neuron cell body and it is of vital importance in the signal transmission between peripheral stimuli and central sensory system. ${ }^{11}$ Admittedly, the pathogenesis of neuropathic pain is complicated. In the beginning, it seems that few neurons were damaged, which led to abnormal electrical activity, synaptic changes and continuous inflammation. ${ }^{12,13}$ Further studies have found that the production of chronic pain includes the abnormal production of pro-inflammatory mediators and the interaction between neurons and immune cells as well. ${ }^{14,15}$ It contains a complex network system composed of microglia and macrophages. ${ }^{15,16}$ For example, colony-stimulating factor 1 (CSF1) induces microglial proliferation and aggravates the pain dramatically. ${ }^{9}$ Reduction of macrophages in DRG can relieve mechanical and thermal hyperalgesia. ${ }^{17}$ Besides, Some new studies show that receptors such as melanocortin 4 receptor (MC4R) and Toll-like receptor 4 (TLR4) are also helpful. ${ }^{18,19}$ Here, we briefly reviewed recent studies of IncRNAs in neuropathic pain, focusing on different rodent neuropathic pain models.

\section{Biological Functions of Long Non-Coding RNAs}

The human transcriptome has pointed that only $1-2 \%$ of the human genome is used to encode proteins, and the remaining $98 \%$ is non-coding RNA. LncRNAs is one of the non-coding RNA without protein-coding function. However, an important progression has been the emergence of lncRNAs as key post-transcriptional regulators. ${ }^{20}$ Crucial roles for IncRNAs have been identified in conditions such as cardiovascular diseases, various cancers, autoimmune disorders, kidney and liver system, etc. ${ }^{21-23}$ Subsequent studies have shown that IncRNAs play an essential role in gene expression by co-transcriptional regulation, post-transcriptional bridging proteins and chromatin, pairing with other RNA and chromosomal modification, ${ }^{24,25}$ especially in the development, proliferation, differentiation, migration and invasion of tumors cells. ${ }^{26}$ What's more, some lncRNAs could play a role in an indirect way, which interacts with microRNAs (miRNAs) and proteins to regulate signal transduction pathways downstream, affecting the development of various diseases. ${ }^{27,28}$

Bioinformatic analysis and silico inference methods reveal potential interactions between IncRNAs-miRNAs and IncRNAs-RNA binding protein, which have attracted intense interest. MiRNAs, small non-coding RNAs, play an important role in the post-transcriptional regulation. ${ }^{27}$ The possible mechanisms for $\operatorname{lncRNAs}$ to regulate miRNA are as follows: (1) lncRNAs indirectly inhibits negative regulation of miRNA by competitively binding to the $3^{\prime}$ UTR of target mRNA. ${ }^{29}$ (2) LncRNAs could act as a competitive endogenous RNA to play the "molecular sponge" and inhibit the expression of miRNA. ${ }^{30,31}$ (3) LncRNAs is a potential pri-miRNA, which indirectly regulates the expression of target genes. ${ }^{32}$ RNA-Protein interactions are key aspects in many biological processes. ${ }^{28}$ The primary concern of the present studies is shifting the attention from RNAs (like tRNAs, rRNAs) involved in translation and regulation towards lncRNAs. ${ }^{20}$ The Encyclopedia of DNA Elements shows that the correspondence between IncRNAs and RBP is not one-to-one. LncRNAs can interact with multiple RBP and generate biological efficacy via regulating expression of genes or preventing association with DNA. ${ }^{33}$ The association between them could be with potential therapeutic implications. While interactions of IncRNAs are more complex than previously thought, it still caused considerable concern and interest. It has been proven that lncRNAs plays an imperative role in tumors and participates in the generation and development of many diseases. In the meantime, a large amount of recent evidence shows that lncRNAs is also essential in neuropathic pain. ${ }^{34}$

\section{The Profiles of Differentially Expressed LncRNAs in Neuropathic Pain}

In recent years, with the rapid improvement of sequencing technology, many studies have conducted more in-depth research on neuropathic pain from the perspective of genes. Stacks of differentially expressed genes were found in the dorsal horn of the spinal cord, DRG and other regions in neuropathic pain models. ${ }^{35}$ Among them, 
it would have indicated that long-chain non-coding RNAs play a fundamental role in disease regulation. Therefore, the lncRNAs will become crucial targets for the treatment of neuropathic pain. ${ }^{36,37}$

Gene sequencing technology was being used in the rat neuropathic pain model to find many differentially expressed genes in the spinal cord and DRG. Therefore, bioinformatics analysis technology can be an ideal method to perform enrichment analysis and construct interactive network, revealing the molecular mechanism of lncRNAs in nerve damage and repair process. ${ }^{36}$ LncRNAs still, in turn, regulate neurite outgrowth of DRG neuron. ${ }^{36} \mathrm{Hu}$ et al identified the differentially expressed lncRNAs in the spared nerve injury (SNL) model and found 1259 downregulated and 2473 up-regulated lncRNAs in SNL rats. Among them, lncRNAs PKIA-AS1, small nucleolar RNA host gene 4(SNHG4), SH3 and cysteine-rich containing protein 3(STAC3) and CIRBP-AS1 were significantly upregulated. $^{38}$ Besides, more than 800 differentially expressed genes have been discovered in the chronic constriction injury model. ${ }^{39}$ A variety of differentially expressed genes were also detected in the neuropathic pain model of mice ${ }^{42-44}$ (Table 1). These studies provide the premise for studying the genetic level of neuropathic pain.

\section{Major Neuropathic Pain Models}

Promising new models for chronic pain provided a good base for further in-depth study of mechanisms. Photochemical and excitotoxic spinal cord injury are main central pain models. But the peripheral models seem to be more popular, which include chronic constriction injury (CCI), SNL, diabetic neuropathic pain (DNP), sciatic nerve injury (SCI) models and so on. In those studies, mechanical and thermal thresholds are important indicators to evaluate the hyperalgesia; and the content of inflammatory mediators usually reflects the degree of neuroinflammation. Nowadays, mature model of peripheral neuropathic pain has been established and major animal models are shown in Figure $1 .{ }^{48}$

\section{Latest Research Advances of LncRNAs in Neuropathic Pain Models}

Based on the numerous researches on neuropathic painrelated lncRNAs, a large number of studies have found that lncRNAs are highly correlated with neuropathic pain, which provides a new target for its treatment.

\section{SNL Model}

There seems many lncRNAs expressed differentially in the SNL model (Table 2). Interaction between the IncRNAs and proteins is important. Firstly, Zhao et al discovered that the voltage-dependent potassium channel-related lncRNAs, KCNA2 antisense RNA, could regulate the excitability of DRG neurons by acting on zinc finger protein in rat, affecting the development and maintenance of neuropathic pain. ${ }^{51}$ The expression of lncRNA H19 in the DRG increased after SNL, and it is mainly up-regulated in Schwann cells - a non-primary sensory neuron, which likely be closely related to neuropathic pain. ${ }^{52}$ Recent studies have found that lncRNA embryonic stem cell expression 1 (lncenc1) is significantly upregulated in the DRG. Lncenc1 could bind to the RNA binding protein (RBP) enhancer of Zeste homologous protein 2 (EZH2), affecting the activation of microglia and the occurrence of neuropathic pain. ${ }^{53} \mathrm{Hu}$ et al performed array analysis on the spinal cord and found that lncRNA PKIA-AS1 is highly expressed in SNL rat model. It has proved that PKIA-AS1 can mediate neuropathic pain by regulating the expression and function of CDK6 in experiments. It seems that most of IncRNAs may interact with receptor indirectly in SNL model.

Besides, lncRNAs directly affects neuropathic pain as well as interacts with miRNAs' downstream. Linc00052 is significantly expressing in the spinal cord of SNL rats. The knockout of Linc00052 can inhibit the neuroinflammatory process through the miR-448-JAK1 axis, alleviating the development of neuropathic pain. ${ }^{54}$ Studies have found that IncRNA p21 has been confirmed in vivo and in vitro experiments that it may act on miR-181b/Tnfaip1 to activate the downstream AKT/CREB axis, regulating cell apoptosis and inflammatory factor secretion, then affecting neuropathic pain. ${ }^{55}$ The small nucleolar RNA host gene (SNHG) family not only involves in the proliferation, metastasis and prognosis of tumors cells, but also affects the progression of neuropathic pain. LncRNA SNHG1 mainly induces pain by directly regulating the level of CDK4 in the spinal cord of SNL rats. ${ }^{56}$ SNHG4 regulates miR-423-5p negatively, which promotes neuro-inflammation and affects the progression of neuropathic pain. ${ }^{57}$ In addition, a significant up-regulation of SNHG5 has been revealed in the mouse SNL model. After knocking out the SNHG5 gene, the mechanical threshold and thermal threshold were significantly increasing. At the same time, the studies suggested that the activation of microglia could 


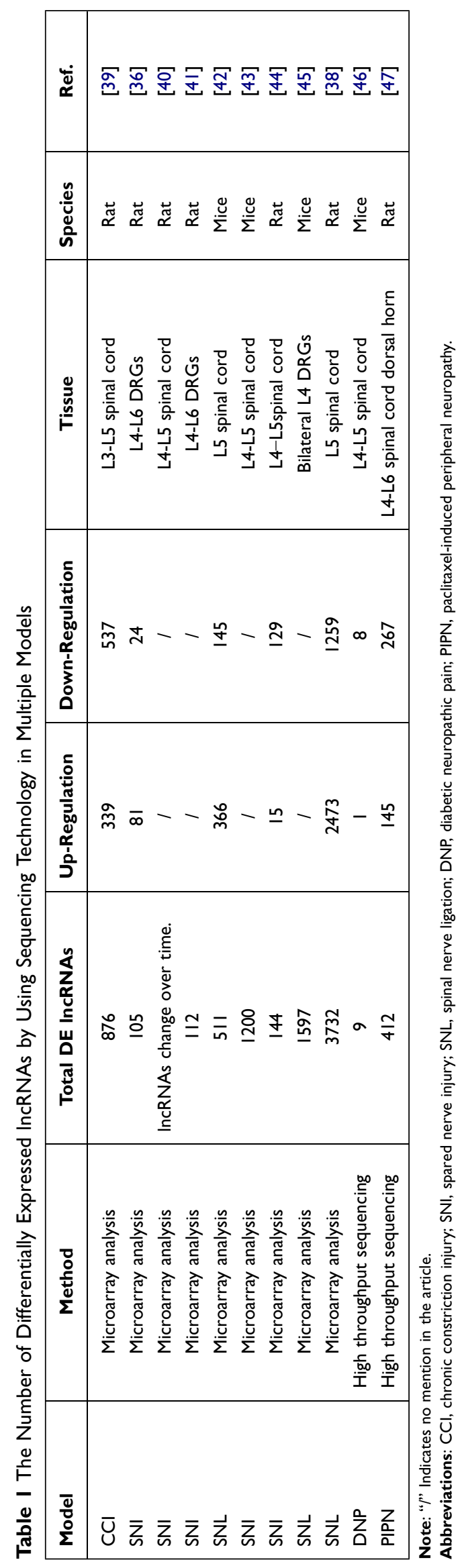

be inhibited by regulating the miR-154-5p/CXCL13 axis, then neuropathic pain is reduced as well. ${ }^{58}$ Such upregulation or downregulation of miRNA was highly correlated with the expression level of IncRNAs in the SNL model. As aforementioned, IncRNAs usually act as a "molecular sponge" to regulate neuroinflammation by lncRNAsmiRNAs axis. The result proven herein, affirms the indispensable role played by miRNA in development of neuropathic pain. As a result, lncRNAs is a new target for the treatment of neuroinflammatory neuropathic pain. ${ }^{38}$

\section{$\mathrm{CCl}$ Model}

A large number of differentially expressed lncRNAs genes related to neuropathic pain were found in the spinal cord and DRG in CCI models (Table 3). Many studies have suggested that IncRNA $\mathrm{X}$-inactive specific transcript (XIST) is significantly up-regulated in the spinal cord tissue and microglia of the CCI model, and it plays a significant role by regulating downstream molecules. For one thing, the development of neuropathic pain can be affected by acting on downstream miR-154-5p, which directs the expression of TLR5. ${ }^{59}$ For another, IncRNA XIST was also reported that it could increase the expression of STAT3 (Signal transducer and activator of transcription 3) by regulating downstream miR-544, which then causes pain aggravation. ${ }^{60}$ Besides, IncRNA XIST can not only negatively regulate miR-150 and zinc-finger E-box-binding (ZEB), ${ }^{61}$ but also act on miR-137 to enhance the expression of TNFAIP1, which can promote inflammation and aggravate the development of neuropathic pain. ${ }^{62}$ It demonstrates that lncRNA XIST plays an essential role in neuropathic pain. The targeted miRNAs of lncRNAs could be predicted by bioinformatics analysis technology, and the interrelations were followed up with animal experiments, which is helpful for the prediction of therapeutic targets. IncRNA MALAT1 (metastasis-associated lung adenocarcinoma transcript 1) is one of the diagnostic markers in many diseases. ${ }^{63,64}$ Research indicated that the expression of IncRNA MALAT1 was significantly up-regulated in the spinal cord and microglia of the CCI model, and it is considered to be a prominent target for pain regulation. Neuropathic pain could be regulated by changing the expression of miR-154-5p and AQP9 by lncRNA MALAT $1{ }^{65}$ LncRNA MALAT1 also interacts with downstream miR-129-5p to regulate the expression of HMGB1 (High-mobility group box 1), which can promote hyperalgesia. ${ }^{66}$ In addition, deletion of MALAT1 gene can alleviate the development of 


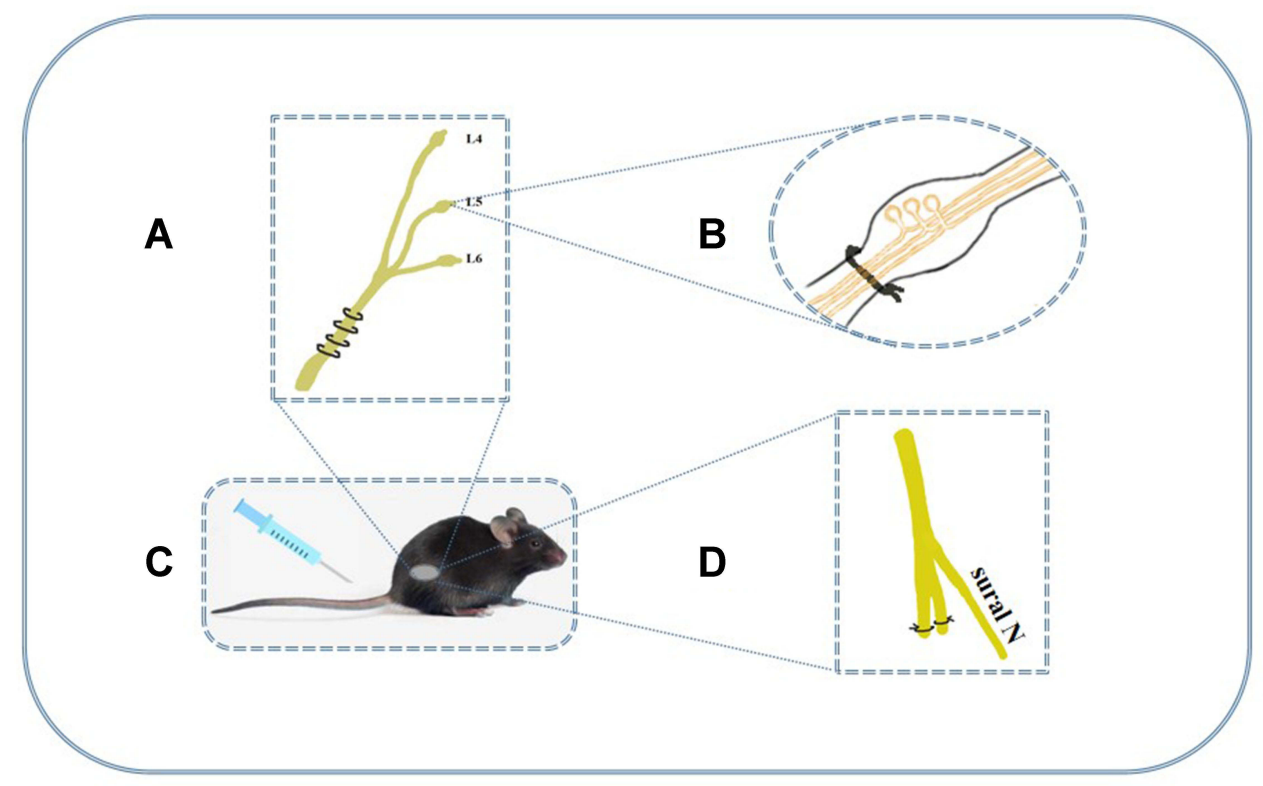

Figure I The major animal models of neuropathic pain. (A) The CCl model loosely ties the unilateral sciatic nerve below the mid-femur region with four chromic gut ligatures. It shows behavioral signs of spontaneous pain and hyperalgesia (thermal and tactile allodynia) and duration of pain signs persist over 2 months. (B) L5 and L6 spinal nerves of SNL model are tied unilaterally and closely at the distal side of dorsal root ganglia. It could indicate allodynia and hyperalgesia and last for at least 4 months. (C) DNP model was established by a single i.p. injection of streptozocin (STZ) and it induces thermal and mechanical hyperalgesia for 2-3 weeks. ${ }^{49}$ (D) In SNI model, the common peroneal and tibial nerves was ligated and axotomized, but sural nerve remained intact. Paw withdrawal threshold after SNI is significantly lower than sham group and hyperpathia lasts for at least I month. ${ }^{50}$

neuroinflammation by inhibiting expression of COX-2, IL$1 \beta$ and IL-6, while promoting up-regulation of miR-206 and inhibiting overexpression of ZEB2, which can improve the progression of neuropathic pain. ${ }^{67}$ LncRNA XIST exists in a variety of biological processes as a ceRNA regulator network of miRNA-mRNA, ${ }^{68}$ and it could potentially be involved in the therapy of neuropathic pain. As can be observed, the pain networks are highly complex and interconnected. For example, the expression of HMGB1 gene can be affected by lncRNA FIRRE and NEAT1 at the same time. Besides, other significantly differentially expressed lncRNAs and the downstream pathway in the CCI model provide new ideas and targets for its treatment.

\section{DNP Model}

The dominating manifestation of DNP model, common complications of type 2 diabetes, is accompanied by a burning sensation, acupuncture sensation and other abnormal sensations. ${ }^{81,82}$ The pathogenesis of diabetic neuropathic pain is complicated. ${ }^{82}$ Most recently, lncRNAs have attracted attention due to the continuous research on the mechanism of diabetic peripheral nerve pain. Related differentially expressed lncRNAs genes were parading in the DNP rat model (Table 4). Liu et al showed that inhibition of lncRNA BC168687 could reverse the threshold of mechanical pain and thermal pain in DNP rats. It mainly interferes with the expression of TRPV1 in DRG and inhibits phosphorylation (P)-ERK and p-p38 signaling pathways at the same time; ${ }^{83}$ They also found that lncRNA BC168687 acts on the P2X7 receptor in DRG, which relieves neuropathic pain by inhibiting its expression. $^{84}$ In addition, lncRNA NONRATT021972 is a gene that plays a pivotal role in DNP. After its expression was inhibited, in the DNP model, results showed that it could interact with the $\mathrm{P} 2 \mathrm{X} 3$ and $\mathrm{P} 2 \mathrm{X} 7$ receptors in DRG to alleviate the development of peripheral pain complications in diabetes. ${ }^{85,86}$ Increased expression of lncRNA uc.48+ was also demonstrated in DNP rat DRG and serum of diabetic patients, which can up-regulate the P2X3 receptor of DRG to regulate the excitability of neurons to affect the development of pain. ${ }^{87}$ Besides, Xiong et al found that IncRNA uc.48+ could promote the release of calcitonin gene-related peptide (CGRP) in the spinal cord. When the expression of IncRNA uc.48+ is down-regulated, it can inhibit the phosphorylation of downstream p38 and ERK1/2, which will reduce the release of IL-1 $\beta$ and TNF- $\alpha$ as well as alleviate hyperalgesia in DNP rats. ${ }^{88}$ It is known that diabetic neuropathy is one of the diabetic complications and the patients are concomitant with maintaining a low quality of life. Now this illustrates 
Table 2 Differential Expression of IncRNAs in SNL Model

\begin{tabular}{|c|c|c|c|c|c|c|c|c|c|}
\hline Model & $\begin{array}{l}\text { Name of } \\
\text { LncRNA }\end{array}$ & $\begin{array}{l}\text { Location of } \\
\text { the Gene }\end{array}$ & $\begin{array}{l}\text { Expression } \\
\text { and } \\
\text { Significance }\end{array}$ & $\begin{array}{l}\text { Pathwayl } \\
\text { Receptor }\end{array}$ & Biological Function & Tissue & Species & Gender & Ref. \\
\hline SNL & $\mathrm{HI9}$ & $\begin{array}{l}\text { Chromosome I } \\
\qquad|q 4|\end{array}$ & $\uparrow *$ & $\begin{array}{l}\text { STAT3/ } \\
\text { TRPAI? }\end{array}$ & Activating inflammatory processes & $\begin{array}{l}\text { Schwann cells/L5 } \\
\text { DRG }\end{array}$ & Rat & Male & [52] \\
\hline SNL & KCNA2 & $\begin{array}{l}\text { Chromosome } 2 \\
2 q 34\end{array}$ & $\downarrow^{* *}$ & MZFI & $\begin{array}{l}\text { Regulation of Kcna2 channel expression and neuronal } \\
\text { excitability }\end{array}$ & L4-L5 DRGs & Rat & - & {$[51]$} \\
\hline SNL & Linc00052 & I & $\uparrow *$ & $\begin{array}{l}\text { miR-448/ } \\
\text { JAKI axis }\end{array}$ & $\begin{array}{l}\text { Regulating the behaviors of neuropathic pain and } \\
\text { processes of neuroinflammation }\end{array}$ & $\begin{array}{l}\text { L4-L6 dorsal spinal } \\
\text { cord }\end{array}$ & Rat & Male & [54] \\
\hline SNL & Lncencl & $\begin{array}{l}\text { Chromosomel3 } \\
\text { I3 DI; } 13\end{array}$ & $\uparrow * *$ & $\begin{array}{l}\text { RBP/EZH2 } \\
\text { axis }\end{array}$ & $\begin{array}{l}\text { The activation of microglia and production of } \\
\text { inflammatory cytokines }\end{array}$ & $\begin{array}{l}\text { L4-L6 DRGs and } \\
\text { microglia }\end{array}$ & Mice & Male & [53] \\
\hline SNL & P2I & l & $\uparrow * *$ & $\begin{array}{l}\text { MiRI8Ib/ } \\
\text { AKT/CREB } \\
\text { axis }\end{array}$ & Promoting apoptosis and inflammatory factors secretion & $\begin{array}{l}\text { L4-L6 dorsal spinal } \\
\text { cords and microglia }\end{array}$ & Rat & Male & [55] \\
\hline SNL & PKIA-ASI & I & $\uparrow *$ & CKD6 & $\begin{array}{l}\text { Directly regulating the expression and function of CDK6 } \\
\text { to maintain neuroinflammation and neuropathic pain }\end{array}$ & L5 spinal cord & Rat & Male & [38] \\
\hline SNL & SNHGI & l & $\uparrow *$ & CKD4 & $\begin{array}{l}\text { Influencing the development of NP by regulating } \\
\text { neuroinflammation }\end{array}$ & L5 spinal cord & Rat & Male & [56] \\
\hline SNL & SNHG4 & $\begin{array}{c}\text { Chromosome } \\
18 \\
|8 p| \mid\end{array}$ & $\uparrow *$ & $\operatorname{miR}-423-5 p$ & $\begin{array}{l}\text { Regulating behaviors of neuropathic pain and } \\
\text { neuroinflammation }\end{array}$ & $\begin{array}{l}\text { L4-L6 dorsal spinal } \\
\text { cord }\end{array}$ & Rat & Male & [57] \\
\hline SNL & SNHG5 & $\begin{array}{l}\text { Chromosome } 9 \\
\text { 9; } 9 \text { E3.I }\end{array}$ & $\uparrow * *$ & $\begin{array}{l}\text { miR-154-5p/ } \\
\text { CXCLI3 } \\
\text { Axis }\end{array}$ & $\begin{array}{l}\text { SNHG5 knockdown alleviated neuropathic pain and } \\
\text { inhibited the activation of astrocytes and microglia }\end{array}$ & L5 DRG & Mice & Male & [58] \\
\hline
\end{tabular}

Notes: "?" Means possible pathway or receptor but has no studies in this article. "l" means no related location of genes were found in specific genera but it does not means absent. "-" indicates no mention in the article; * means $\mathrm{P}<$ 0.05 , ** means $\mathrm{P}<0.01$.

Abbreviations: KCNA2-AS, KCNA2 antisense RNA; Lncencl, LncRNA embryonic stem cells expressed I; MZFI, myeloid zinc finger protein I; SNHG, small nucleolar RNA host gene; EZH2, enhancer of zeste 2 polycomb repressive complex 2 subunits; CDK, cyclin dependent kinase; CXCLI3, C-X-C motif chemokine ligand I3. 


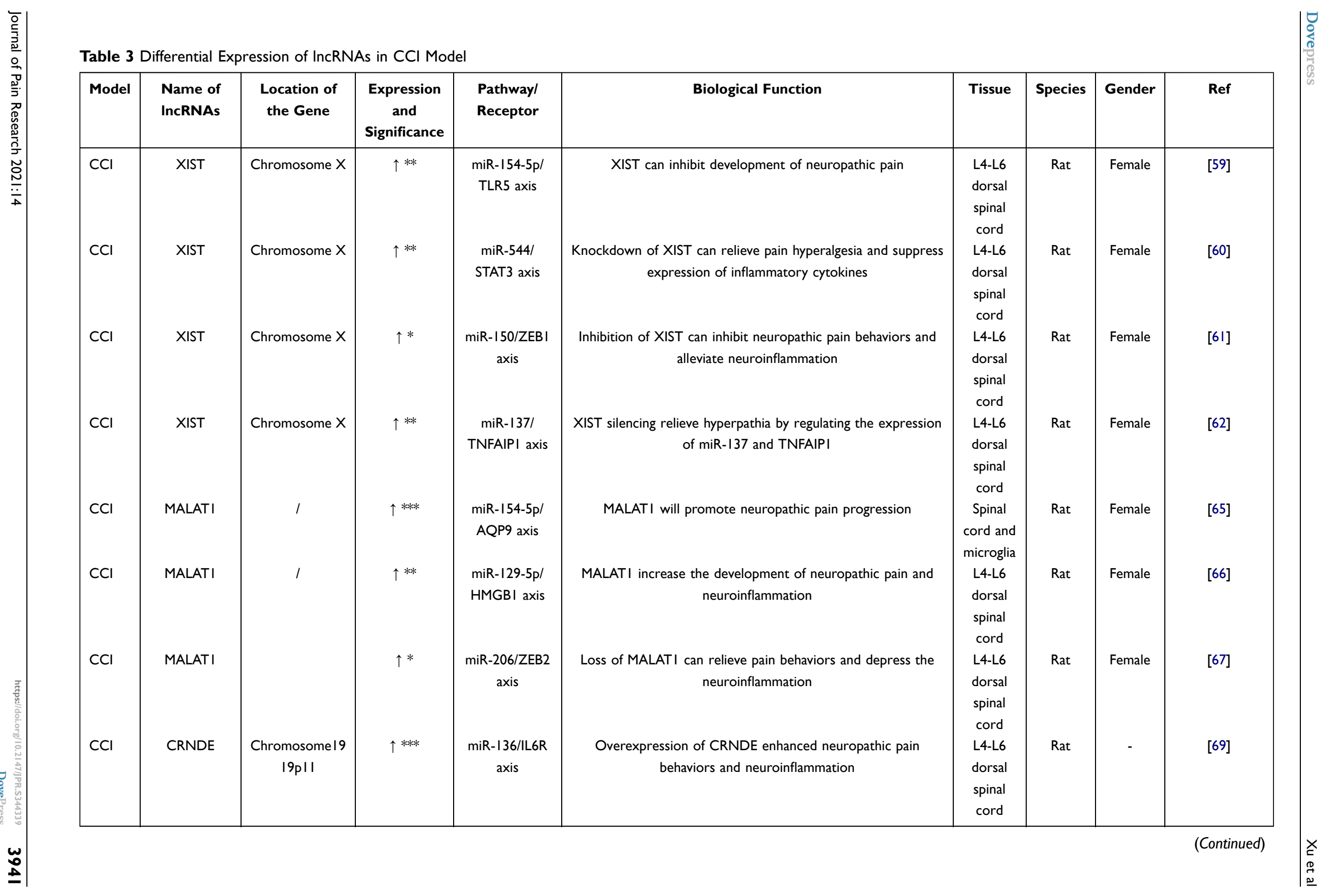


Table 3 (Continued).

\begin{tabular}{|c|c|c|c|c|c|c|c|c|c|}
\hline Model & $\begin{array}{l}\text { Name of } \\
\text { IncRNAs }\end{array}$ & $\begin{array}{l}\text { Location of } \\
\text { the Gene }\end{array}$ & $\begin{array}{l}\text { Expression } \\
\quad \text { and } \\
\text { Significance }\end{array}$ & $\begin{array}{l}\text { Pathwayl } \\
\text { Receptor }\end{array}$ & Biological Function & Tissue & Species & Gender & Ref \\
\hline $\mathrm{CCl}$ & DGCR5 & I & $\downarrow *$ & $\begin{array}{l}\text { miR-330-3p/ } \\
\text { PDCD4 axis }\end{array}$ & $\begin{array}{l}\text { DGCR5 overexpression can alleviate neuropathic pain } \\
\text { development }\end{array}$ & $\begin{array}{l}\text { L4-L6 } \\
\text { dorsal } \\
\text { spinal } \\
\text { cord }\end{array}$ & Rat & - & [70] \\
\hline $\mathrm{CCl}$ & FIRRE & $\begin{array}{l}\text { Chromosome X } \\
\quad \text { X; X A5 }\end{array}$ & $\uparrow *$ & HMGBI & $\begin{array}{l}\text { LncRNA FIRRE downregulation inhibits the secretion of } \\
\text { microglial cells-rived inflammatory cytokines }\end{array}$ & $\begin{array}{l}\text { L4-L6 } \\
\text { spinal } \\
\text { cord }\end{array}$ & Mice & Female & [7I] \\
\hline $\mathrm{CCl}$ & Gas5 & $\begin{array}{l}\text { Chromosomel3 } \\
13 q 22\end{array}$ & $\downarrow *$ & $\begin{array}{l}\text { miR-452-5p/ } \\
\text { CELF2 axis }\end{array}$ & $\begin{array}{l}\text { GAS5 overexpression will mitigate mechanical allodynia and } \\
\text { thermal hyperalgesia }\end{array}$ & $\begin{array}{l}\text { Spinal } \\
\text { cord and } \\
\text { microglia }\end{array}$ & Rat & Female & [72] \\
\hline $\mathrm{CCl}$ & LINC00657 & l & $\uparrow *$ & $\begin{array}{l}\mathrm{miR}-|36 / Z E B| \\
\text { axis }\end{array}$ & $\begin{array}{l}\text { Knockdown of LINC00657 will inhibit the neuroinflammation } \\
\text { and alleviate hyperalgesia }\end{array}$ & $\begin{array}{l}\text { L4-L6 } \\
\text { dorsal } \\
\text { spinal } \\
\text { cord }\end{array}$ & Rat & Female & [73] \\
\hline $\mathrm{CCl}$ & NEATI & l & $\uparrow^{*}$ & $\begin{array}{l}\text { miR-38I/ } \\
\text { HMGBI axis }\end{array}$ & $\begin{array}{l}\text { Knockdown of NEATI can repress neuropathic pain behaviors } \\
\text { and inhibiting expression of IL-6, IL-I } \beta \text {, and TNF- } \alpha\end{array}$ & $\begin{array}{l}\text { L4-L6 } \\
\text { dorsal } \\
\text { spinal } \\
\text { cord }\end{array}$ & Rat & Female & [74] \\
\hline $\mathrm{CCl}$ & DLEUI & I & $\uparrow *$ & $\begin{array}{l}\text { miR-I33a-3p/ } \\
\text { SRPKI axis }\end{array}$ & $\begin{array}{c}\text { DLEUI knockdown reduces the neuroinflammation and } \\
\text { inhibited neuropathic pain behaviors }\end{array}$ & $\begin{array}{l}\text { Dorsal } \\
\text { spinal } \\
\text { cord }\end{array}$ & Rat & Female & [75] \\
\hline $\mathrm{CCl}$ & $\mathrm{HI9}$ & $\begin{array}{c}\text { Chromosome I } \\
|q 4|\end{array}$ & $\uparrow * *$ & $\begin{array}{l}\text { miR-196a-5p/ } \\
\text { CDK5 axis }\end{array}$ & $\begin{array}{l}\text { Overexpression of } \mathrm{HI} 9 \text { can alleviate hyperalgesia and upregulate } \\
\text { inflammatory factors and GFAP levels, and reduced expression } \\
\text { of } 5-\mathrm{HT} 2 \mathrm{~A} \text { and GABAB2 }\end{array}$ & $\begin{array}{l}\text { L4-L5 } \\
\text { dorsal } \\
\text { spinal } \\
\text { cord }\end{array}$ & Rat & - & [76] \\
\hline $\mathrm{CCl}$ & MRAK0097I3 & l & $\uparrow * *$ & P2X3 receptor & $\begin{array}{c}\text { Highly expressed MRAK0097/3 markedly increased pain } \\
\text { behaviors and expression of P2X3 }\end{array}$ & DRG & Rat & Male & [77] \\
\hline $\mathrm{CCl}$ & SNHGI6 & I & $\uparrow * * *$ & $\begin{array}{l}\text { miR-I24-3p } \\
\text { and miR-I4I- } \\
\text { 3p/JAGI axis }\end{array}$ & $\begin{array}{l}\text { SNHGI } 6 \text { could increase the mechanical allodynia and thermal } \\
\text { hyperalgesia and mRNA expression of inflammatory factors }\end{array}$ & $\begin{array}{l}\text { Dorsal } \\
\text { spinal } \\
\text { cord }\end{array}$ & Rat & Female & [78] \\
\hline $\mathrm{CCl}$ & uc. 153 & I & $\uparrow * * *$ & $\begin{array}{c}\text { miR-182-5p/ } \\
\text { EphBI-NMDA } \\
\text { axis }\end{array}$ & uc. I53 will promote pain behaviors and neuronal sensitization & $\begin{array}{l}\text { L4-L5 } \\
\text { dorsal } \\
\text { spinal } \\
\text { cord }\end{array}$ & Mice & Male & [79] \\
\hline
\end{tabular}




\begin{tabular}{|c|c|c|c|c|c|c|c|c|c|}
\hline $\mathrm{CCl}$ & CRNDE & $\begin{array}{l}\text { Chromosomel9 } \\
19 \mathrm{p} \mid 1\end{array}$ & $\uparrow * * *$ & $\begin{array}{l}\text { miR-146a-5p/ } \\
\text { WNT5A }\end{array}$ & $\begin{array}{l}\text { Silencing of CRNDE relieved mechanical allodynia, thermal } \\
\text { hyperalgesia, and neuroinflammation }\end{array}$ & $\begin{array}{l}\text { Dorsal } \\
\text { spinal } \\
\text { cord }\end{array}$ & Rat & Male & [80] \\
\hline $\mathrm{CCl}$ & MEG3 & 1 & $\uparrow * * *$ & $\begin{array}{c}\text { miR-130a-5p/ } \\
\text { CXCLI2/ } \\
\text { CXCR4 }\end{array}$ & $\begin{array}{l}\text { Up-regulating MEG3 aggravated NP, enhanced inflammatory } \\
\text { cytokines expression and release. }\end{array}$ & $\begin{array}{l}\text { L4-L6 } \\
\text { dorsal } \\
\text { spinal } \\
\text { cord }\end{array}$ & Rat & Female & [80] \\
\hline $\mathrm{CCl}$ & PCATI9 & 1 & $\uparrow * * *$ & $\begin{array}{l}\text { miR- } 182-5 \mathrm{p} / \\
\text { JMJDIA }\end{array}$ & $\begin{array}{l}\text { Mechanical pain and thermal hyperalgesia as well as } \\
\text { neuroinflammation can be reduced by knocking down PCATI9 }\end{array}$ & $\begin{array}{l}\text { L4-L6 } \\
\text { dorsal } \\
\text { spinal } \\
\text { cord }\end{array}$ & Rat & Male & [80] \\
\hline
\end{tabular}

Notes: "l" Means no related location of genes were found in specific genera but it does not means absent. "." indicates no mention in the article; * means $\mathrm{P}<0.05$, ** means $\mathrm{P}<0.0 \mathrm{I}$, and *** means $\mathrm{P}<0.00 \mathrm{I}$.

Abbreviations: DGCR5, DiGeorge syndrome critical region gene 5; NEATI, Nuclear paraspeckle assembly transcript I; XIST, X inactivation-specific transcript; DLEUI, deleted in lymphocytic leukemia I; MALATI, metastasis-associated lung adenocarcinoma transcript I; SNHG, small nucleolar RNA host gene; CRNDE, Colorectal neoplasia differentially expressed; FIRRE, functional intergenic repeating RNA element; Gas5, growth arrest-specific transcript 5. MEG3, maternally expressed 3; PCATI9, prostate cancer associated transcript 19; TLR5, toll like receptor 5; STAT3, signal transducer and activator of transcription 3; TNFAIPI, TNF alpha induced protein I; AQP9, aquaporin 9; HMGBI, high mobility group box I; ZEB2L, zinc finger E-box binding homeobox 2; PDCD4, programmed cell death 4; CELF2, CUGBP Elav-like family member 2; SRPKI, SRSF protein kinase I; CDK5, cyclin dependent kinase 5; WNT5A, Wnt family member 5A; CXCLI2, C-X-C motif chemokine ligand 12; CXCR4, C-X-C motif chemokine receptor 4; JMJDIA, lysine demethylase 3A.

Table 4 Differential Expression of IncRNAs in CCI Model. GENE

\begin{tabular}{|c|c|c|c|c|c|c|c|c|}
\hline Model & $\begin{array}{l}\text { Name of } \\
\text { IncRNAs }\end{array}$ & $\begin{array}{c}\text { Expression } \\
\text { and } \\
\text { Significance }\end{array}$ & $\begin{array}{l}\text { Pathwayl } \\
\text { Receptor }\end{array}$ & Biological Function & Tissue & Species & Gender & Ref \\
\hline DNP & $\mathrm{BCI} 68687$ & $\uparrow-$ & TRPVI & It could increase diabetic neuropathic pain by acting TRPVI receptor & DRG & Rat & Male & [83] \\
\hline DNP & $\mathrm{BCI} 68687$ & $\uparrow * *$ & $\mathrm{P} 2 \mathrm{X} 7$ & $\begin{array}{l}\mathrm{BC} 168687 \text { could increase the release of } \mathrm{NO} \text { and the activation of } \mathrm{SGCs} \text {, thus } \\
\text { regulate the excitability of } \mathrm{DRG} \text { neurons and the pain behaviors }\end{array}$ & DRG & Rat & Male & {$[84]$} \\
\hline DNP & NONRATT021972 & $\uparrow * *$ & $\mathrm{P} 2 \times 3$ & $\begin{array}{l}\text { It could aggravate thermal and mechanical hyperalgesia vis activating } \mathrm{P} 2 \mathrm{X} 3 \\
\text { receptor of ERKI/2 }\end{array}$ & DRG & Rat & Male & {$[85]$} \\
\hline DNP & NONRATT021972 & $\uparrow * * *$ & $\mathrm{P} 2 \mathrm{X} 7$ & $\begin{array}{l}\text { It can increase the expression levels of P2X7 and activation of satellite glial cells } \\
\text { in DRG }\end{array}$ & DRG & Rat & - & {$[86]$} \\
\hline DNP & uc. $48+$ & $\uparrow * *$ & $\mathrm{P} 2 \times 3$ & $\begin{array}{l}\text { uc. } 48+\text { may regulate the excitatory of primary sensory neurons by the } \mathrm{P} 2 \mathrm{X} 3 \\
\text { receptor }\end{array}$ & DRG & Rat & Male & {$[87]$} \\
\hline DNP & uc. $48+$ & $\uparrow * *$ & $\begin{array}{l}\text { P38 and } \\
\text { ERKI/2 }\end{array}$ & IncRNA uc. $48+$ may regulate DNP by promoting the release of CGRP & $\begin{array}{l}\text { L4-L5 } \\
\text { spinal } \\
\text { cords }\end{array}$ & Rat & Male & {$[88]$} \\
\hline
\end{tabular}


neuroinflammation and microglia activation are critical in origination and development of DNP. Therefore, these related lncRNAs may become noteworthy targets for the treatment of DNP in the future.

\section{Other Neuropathic Pain Models}

Moreover, lncRNAs are found to be actively involved in other models (Table 5). Trigeminal neuralgia (TN) is also a prevalent neuropathic pain in clinical practice. Cai et al found that IncRNA Gm14461 is related to the activation and autophagy of astrocytes in a mouse model of trigeminal neuralgia. When the lncRNA was silencing, loss of Gm14461 increased autophagy in astrocytes and played an analgesic effect by regulating AMPK and Akt/mTOR signaling pathways. ${ }^{89}$ LncRNA Gm14461 is also a factor to regulate CGRP (calcitonin gene-related peptide) and P2X3/ 7 receptors, which affect the release of inflammatory mediators and pain. ${ }^{90}$ Similar to the role of IncRNA uc. $48+$ in the DNP model, in the TN model, lncRNA uc.48+ will upregulate the expression of $\mathrm{P} 2 \mathrm{X} 7$ receptors and enhance the phosphorylation of ERK1/2 in the trigeminal nerve meridian, which will heighten pain sensitization. ${ }^{91}$ In the rat brachial plexus injury (BPI) model, the expression of lncRNA Malat1 decreases in the spinal cord, which may affect the excitability of neurons by regulating the level of calcium ions. ${ }^{92}$ In addition, up-regulation of JHDM1D-AS1 can reduce the inflammation and neuronal damage of the spinal cord after brachial plexus injury by targeting miR101-3p-DUSP. ${ }^{93}$ In the rat model of cancer pain, the expression of lncRNA-NONRATT021203.2 was increased, which can participate in the production of pain by targeting CXCL9 (C-X-C motif chemokine ligand 9). ${ }^{94}$ Postherpetic neuralgia (PHN) is also a considerable neuropathic pain. It confirmed that KCNA2-AS is highly expressing in the spinal cord of the PHN (postherpetic neuralgia) rat model. The pain is relieved when KCNA2-AS was knocking out. The possible reason is that it reduces the translocation of pSTAT3 to the nucleus and inhibits the activation of astrocytes. ${ }^{95}$ However, lncRNA NEAT1 can target the expression of AQP4 by inhibiting miR-128-3p in the rat SCI model, which affects the development of neuropathic pain. ${ }^{96}$ SNI (spare nerve injury) model as a common model in neuropathic pain research. But there are few reliable studies of lncRNAs in this model. Silencing of LINC01119 can alleviate the hypersensitivity and reduced the increase in $\mathrm{IL}-6, \mathrm{IL}-1 \beta$, and $\mathrm{TNF}-\alpha$ via binding with ELAVL1 and increasing BDNF mRNA stability and expression level. Here, we briefly reviewed recent studies of IncRNAs in neuropathic pain, focusing on different rodent neuropathic pain models. Many expressions of IncRNAs are altered in rodent rats after the establishment of chronic pain. Therefore, lncRNAs might be a good potential therapeutic target for neuropathic pain.

\section{Discussion and Future Perspectives}

Chronic neuropathic pain is a severe situation, accompanying by injury and dysfunction of the somatosensory nervous system. ${ }^{6}$ However, at present, a lack of efficient curative treatments remains a severe challenge for neuropathic pain. It proved that the rodent models of chronic neuropathic pain play an essential role in parent studies. And detailed intermolecular interactions such as lncRNAs and miRNAs were revealed, which could provide therapeutic promise for the treatment of chronic neuropathic pain.

With the advance in sequencing technology, the studies of lncRNAs in have become a hotspot of the filed. It has been demonstrated that played an essential role in neuropathic pain. Therefore, lncRNAs are likely expected to become a potential target for neuropathic pain. We wonder if these sequencing results of lncRNAs are reliable. For instance, even within the same model there are major differences among sequencing studies published in the literature. The sequencing technology should exhibit excellent sensitivity, repeatability, and stability. In other words, the current study confirms that lncRNAs lack specificity in different models. Perhaps due to complex influencing factors in the system, a few discrepancies are evident in the sequencing results.

As is well known, lncRNAs do not participate in protein-coding directly. However, it plays an imperative part in co-transcriptional regulation, post-transcriptional and Post-translational protein modifications and so on. ${ }^{20}$ Related research found that the potential regulatory effect of IncRNAs is very distinguished in various diseases. In the above experiments of different neuropathic pain animal models, but also present a significant role in regulating the generation as well as the progression of neuropathic pain. The previous focus was mainly on the changes in the excitability of central and peripheral sensory neurons and the interaction of surrounding microglia, macrophages and other immune cells in the research of neuropathic pain, which led to the persistence of pain signals. What's more, we have shown in this review that the interactions of the lncRNAs, miRNA and proteins are very complicated. As such, the studies of those non-coding RNAs can be used to 
Table 5 Differential Expression of IncRNAs in Other Models

\begin{tabular}{|c|c|c|c|c|c|c|c|c|c|}
\hline Model & $\begin{array}{l}\text { Name of } \\
\text { IncRNAs }\end{array}$ & $\begin{array}{l}\text { Location of } \\
\text { the Gene }\end{array}$ & $\begin{array}{l}\text { Expression } \\
\quad \text { and } \\
\text { Significance }\end{array}$ & $\begin{array}{l}\text { Pathwayl } \\
\text { Receptor }\end{array}$ & Biological Function & Tissue & Species & Gender & Ref. \\
\hline TN & Gm|446| & $\begin{array}{l}\text { Chromosome2 } \\
\quad 2 \text { C3; } 2\end{array}$ & $\uparrow * *$ & $\begin{array}{c}\text { AMPK and } \\
\text { Akt/mTOR } \\
\text { signaling }\end{array}$ & $\begin{array}{l}\text { Gm I } 446 \text { I silencing relieves mechanical withdrawal threshold and } \\
\text { inhibits astrocyte activation and enhances autophagy via regulating of } \\
\text { the AMPK and Akt/mTOR signaling }\end{array}$ & $\begin{array}{l}\text { Trigeminal } \\
\text { ganglia }\end{array}$ & Mice & - & [89] \\
\hline TN & Gm|446| & $\begin{array}{l}\text { Chromosome2 } \\
\quad 2 \text { C } 3 ; 2\end{array}$ & $\uparrow *$ & $\begin{array}{l}\text { CGRP and } \\
\text { P2X3/7 } \\
\text { receptor }\end{array}$ & $\begin{array}{l}\text { GmI } 4461 \text { overexpression decreases MWT and upregulates mRNA } \\
\text { levels of proinflammatory cytokine and protein levels of CGRP and } \\
\text { P2X3/7 receptor }\end{array}$ & $\begin{array}{l}\text { Trigeminal } \\
\text { ganglia }\end{array}$ & Mice & & [90] \\
\hline TN & uc.48+ & 1 & $\uparrow * *$ & $\begin{array}{l}\mathrm{P} 2 \mathrm{X} 7 \mathrm{I} \\
\mathrm{ERKI} / 2\end{array}$ & uc. $48+$ can activate the $P 2 \times 7$ receptor to regulate the $M W T$ & $\begin{array}{l}\text { Trigeminal } \\
\text { ganglia }\end{array}$ & Rat & Male & [9I] \\
\hline BPI & MalatI & I & $\downarrow *$ & Unknown & $\begin{array}{l}\text { Down-regulation of Malatl increases the frequency of spontaneous } \\
\text { electric activity via changing of intracellular calcium concentration in } \\
\text { neurons but have no effect on neuronal apoptosis. }\end{array}$ & $\begin{array}{l}\text { C5-TI } \\
\text { spinal cord }\end{array}$ & Rat & Male & [92] \\
\hline CIP & $\begin{array}{l}\text { NONRATT } \\
021203.2\end{array}$ & 1 & $\uparrow^{*}$ & CXCL9 & $\begin{array}{c}\text { LncRNA-NONRATT02 I } 203.2 \text { could target CXCL9 to regulate } \\
\text { hyperalgesia }\end{array}$ & DRG & Rat & Female & [94] \\
\hline PHN & KCNA2 & $\begin{array}{c}\text { Chromosome } \\
2 \\
2 q 34\end{array}$ & $\downarrow * *$ & STAT3 & $\begin{array}{l}\text { KCNA2-AS relieved mechanical allodynia partly by combining with } \\
\text { PSTAT3 to regulate cytoplasmic/nuclear translocation. }\end{array}$ & Spinal cord & Rat & Female & [95] \\
\hline $\mathrm{sCl}$ & NEATI & 1 & $\uparrow * * *$ & $\begin{array}{l}\text { miR-128-3p/ } \\
\text { AQP4 axis }\end{array}$ & $\begin{array}{l}\text { Over-expression of NEATI enhance the expression of inflammatory } \\
\text { factors (LL-6, IL-I } \beta \text {, and TNF } \alpha \text { ) }\end{array}$ & Spinal cord & Rat & Female & [96] \\
\hline $\mathrm{SCl}$ & PVTI & $\begin{array}{l}\text { Chromosome } \\
\quad 6 \\
7 \mathrm{q} 33\end{array}$ & $\uparrow * * *$ & $\begin{array}{c}\text { miR-186-5p/ } \\
\text { CXCLI3/ } \\
\text { CXCR5 } \\
\text { Axis }\end{array}$ & $\begin{array}{l}\text { PVTI depletion could alleviated pain behaviors, astrocytic activation } \\
\text { and reduced the expression of neuroinflammatory cytokine }\end{array}$ & $\begin{array}{l}\text { TI0 spinal } \\
\text { cord }\end{array}$ & Rat & Male & [97] \\
\hline BPI & $\begin{array}{l}\text { JHDMID- } \\
\text { ASI }\end{array}$ & $\begin{array}{l}\text { Chromosome } \\
\quad 6 \\
4 \mathrm{q} 22\end{array}$ & $\downarrow * * *$ & $\begin{array}{l}\text { miR-I0I-3p/ } \\
\text { DUSPI axis }\end{array}$ & $\begin{array}{l}\text { JHDMID-ASI have a neuroprotective effect by suppressing neuronal } \\
\text { apoptosis and microglial activation }\end{array}$ & Spinal cord & Rat & & [93] \\
\hline SNI & LINCOIII9 & $\begin{array}{l}\text { Chromosome } \\
6 \\
2 \mathrm{p} 21\end{array}$ & $\uparrow * *$ & $\begin{array}{l}\text { ELAVLI/ } \\
\text { BDNF }\end{array}$ & $\begin{array}{c}\text { Silencing of } L I N C 0 I / 19 \text { can alleviate the hypersensitivity and reduced } \\
\text { the increase in IL-6, IL-I } 1 \text {, and TNF-a via binding with ELAVLI and } \\
\text { increasing BDNF mRNA stability and expression level. }\end{array}$ & $\begin{array}{l}\text { L4- } \\
\text { L5spinal } \\
\text { cord; } \\
\text { serum }\end{array}$ & $\begin{array}{l}\text { Rat; } \\
\text { Human }\end{array}$ & Male & [98] \\
\hline
\end{tabular}

Notes: "l" Means no related location of genes were found in specific genera but it does not means absent. * means $\mathrm{P}<0.05$, ** means $\mathrm{P}<0.0 \mathrm{l}$, and *** means $\mathrm{P}<0.00 \mathrm{I}$; “-" indicates no mention in the article.

Abbreviations: TN, trigeminal neuralgia; BPI, brachial plexus injury; PHN, post-herpetic neuralgia; SCI, spinal cord injury; PHN, postherpetic neuralgia; CIP, Cancer-induced pain; MWT, mechanical withdrawal threshold; SNI, spare nerve injury; MALATI, metastasis-associated lung adenocarcinoma transcript I; PVTI, plasmacytoma variant translocation I; KCNA2-AS, KCNA2 antisense RNA; NEATI, Nuclear paraspeckle assembly transcript I; JHDMID-ASI, JHDMID antisense I; Mtor, mechanistic target of rapamycin kinase; STAT3, signal transducer and activator of transcription 3; DUSPI, dual specificity phosphatase I; ELAVLI, ELAV like RNA binding protein I; BDNF, brain derived neurotrophic factor. 
understand better the mechanisms of molecular interaction. Current works of lncRNAs have been shown in Figure 2. However, there is limited research focused on clinical prospective studies of lncRNAs in neuropathic pain. Because of neurocytes are nonrenewable, human specimens are generally available. Currently, several researches are focusing attention on the animal and cell studies.

Gender differences of immune cells were found among the neuropathic pain. The magnitude of the injury-induced macrophage expansion was different between the female and male mice. ${ }^{16}$ Microglia also showed sex differences. It is critical to the development of the neuropathic pain in male mice but not in female. ${ }^{99}$ No previous studies have, however, investigated the differentially expressed lncRNAs in neuropathic pain models of different sex. The exact role of lncRNAs in mediating hypersensitivity in sexually dimorphic is still to be defined in the in the subsequent studies.

In conclusion, current results of IncRNAs in neuropathic pain indicate the potential of using sequencing technology. Despite the current researches lacking clinical implications and specificity of lncRNAs in different models, sufficient evidence has been presented to prove that IncRNAs have critical roles in the development of neuropathic pain. Therefore, additional studies are required to look for potential specific biomarkers and treatment in neuropathic pain from basic research to clinical applications.

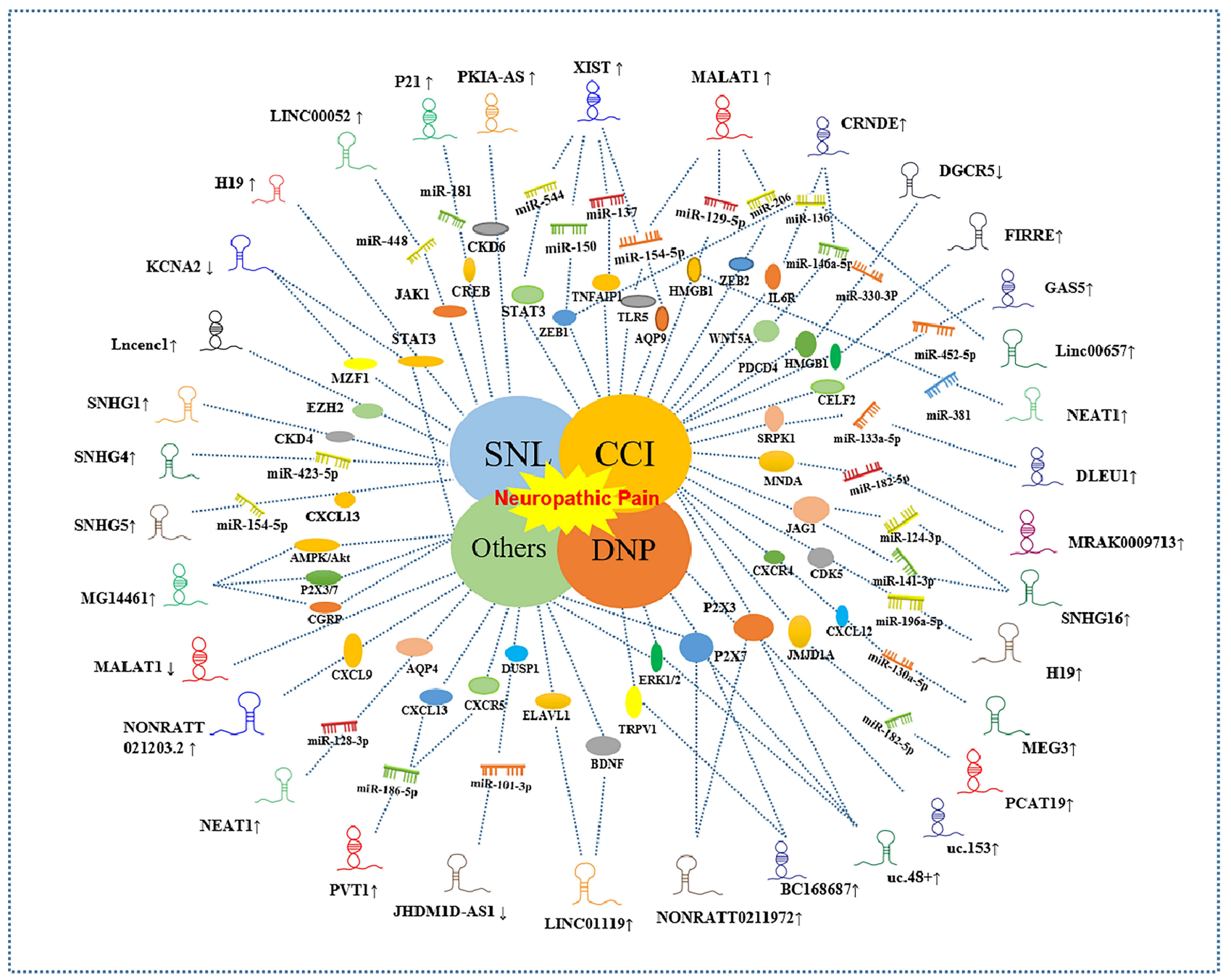

Figure 2 Differentially expressed IncRNA in differential neuropathic pain models. $\uparrow$ : up-regulation; $\downarrow$ : down-regulation. Differential shapes of IncRNAs denote gene symbol without biological meaning. Center works represent different models of neuropathic pain. 


\section{Acknowledgments}

The authors are grateful for support from the Qingdao University Medical Research Center.

The authors thank Citexs (www.citexs.com) for English language editing.

This work was supported by Youth Research Fund of Affiliated Hospital of Qingdao University (for YZ).

\section{Author Contributions}

All authors made a significant contribution to the work reported, whether that is in the conception, study design, execution, acquisition of data, analysis and interpretation, or in all these areas; took part in drafting, revising or critically reviewing the article; gave final approval of the version to be published; have agreed on the journal to which the article has been submitted; and agree to be accountable for all aspects of the work.

\section{Disclosure}

The authors have no conflicts of interest to declare.

\section{References}

1. Inoue K, Tsuda M. Microglia in neuropathic pain: cellular and molecular mechanisms and therapeutic potential. Nat Rev Neurosci. 2018;19(3):138-152. doi:10.1038/nrn.2018.2

2. Ochoa JL. Neuropathic pain: redefinition and a grading system for clinical and research purposes. Neurology. 2009;72(14):1282-1283. doi:10.1212/01.wnl.0000346325.50431.5f

3. Scholz J, Finnerup NB, Attal N, et al. The IASP classification of chronic pain for ICD-11: chronic neuropathic pain. Pain. 2019;160 (1):53-59. doi:10.1097/j.pain.0000000000001365

4. Borzan J, Meyer RA. Neuropathic Pain. Encycl Neurosci. 2009; Imi:749-757.

5. Andersen ML, Araujo P, Frange C, Tufik S. Sleep disturbance and pain: a tale of two common problems. Chest. 2018;154(5):12491259. doi:10.1016/j.chest.2018.07.019

6. Gilron I, Baron R, Jensen T. Neuropathic pain: principles of diagnosis and treatment. Mayo Clin Proc. 2015;90(4):532-545. doi:10.1016/j. mayocp.2015.01.018

7. Li Y, North RY, Rhines LD, et al. DRG voltage-gated sodium channel 1.7 is upregulated in paclitaxel-induced neuropathy in rats and in humans with neuropathic pain. J Neurosci. 2018;38(5):1124-1136. doi:10.1523/JNEUROSCI.0899-17.2017

8. Li N, Liu B, Wu W, et al. Upregulation of transcription factor 4 downregulates NaV1.8 expression in DRG neurons and prevents the development of rat inflammatory and neuropathic hypersensitivity. Exp Neurol. 2020;327:113240. doi:10.1016/j.expneurol.2020.113240

9. Guan Z, Kuhn JA, Wang X, et al. Injured sensory neuron-derived CSF1 induces microglial proliferation and DAP12-dependent pain. Nat Neurosci. 2015;19(1):94-101. doi:10.1038/nn.4189

10. Davoli-Ferreira M, De Lima KA, Fonseca MM, et al. Regulatory T cells counteract neuropathic pain through inhibition of the Th1 response at the site of peripheral nerve injury. Pain. 2020;161 (8):1730-1743. doi:10.1097/j.pain.0000000000001879
11. Hogan QH. Labat lecture: the primary sensory neuron: where it is, what it does, and why it matters. Reg Anesth Pain Med. 2010;35 (3):306-311. doi:10.1097/AAP.0b013e3181d2375e

12. Taylor BK. Pathophysiologic mechanisms of neuropathic pain. Curr Pain Headache Rep. 2001;5(2):151-161. doi:10.1007/s11916-0010083-1

13. Sommer C, Leinders M, Üçeyler N. Inflammation in the pathophysiology of neuropathic pain. Pain. 2018;159(3):595-602. doi:10.1097/j.pain.0000000000001122

14. Scholz J, Woolf CJ. The neuropathic pain triad: neurons, immune cells and glia. Nat Neurosci. 2007;10(11):1361-1368. doi:10.1038/ nn1992

15. Tozaki-Saitoh H, Tsuda M. Microglia-neuron interactions in the models of neuropathic pain. Biochem Pharmacol. 2019;169:113614. doi:10.1016/j.bcp.2019.08.016

16. Yu X, Liu H, Hamel KA, et al. Dorsal root ganglion macrophages contribute to both the initiation and persistence of neuropathic pain. Nat Commun. 2020;11(1):1-12. doi:10.1038/s41467-019-13993-7

17. Yu X, Leff J, Guan Z. Rapid isolation of dorsal root ganglion macrophages. J Vis Exp. 2019;2019(151):2-6.

18. Zhao Y, Xin Y, Chu H. MC4R is involved in neuropathic pain by regulating JNK signaling pathway after chronic constriction injury. Front Neurosci. 2019;13:1-11. doi:10.3389/fnins.2019.00919

19. Bruno K, Woller SA, Miller YI, et al. Targeting toll-like receptor-4 (TLR4)-an emerging therapeutic target for persistent pain states. Pain. 2018;159(10):1908-1915. doi:10.1097/j.pain.0000000000001306

20. Bali KK, Kuner R. Noncoding RNAs: key molecules in understanding and treating pain. Trends Mol Med. 2014;20(8):437-448. doi:10.1016/j.molmed.2014.05.006

21. Nandwani A, Rathore S, Datta M. LncRNAs in cancer: regulatory and therapeutic implications. Cancer Lett. 2021;501:162-171. doi:10.1016/j.canlet.2020.11.048

22. Wu GC, Pan HF, Leng RX, et al. Emerging role of long noncoding RNAs in autoimmune diseases. Autoimmun Rev. 2015;14(9):798805. doi:10.1016/j.autrev.2015.05.004

23. Lorenzen JM, Thum T. Long noncoding RNAs in kidney and cardiovascular diseases. Nat Rev Nephrol. 2016;12(6):360-373. doi:10.1038/nrneph.2016.51

24. Ulitsky I, Bartel DP. XLincRNAs: genomics, evolution, and mechanisms. Cell. 2013;154(1):26. doi:10.1016/j.cell.2013.06.020

25. Li Z, Li X, Chen X, et al. Emerging roles of long non-coding RNAs in neuropathic pain. Cell Prolif. 2019;52(1):1-7. doi:10.1111/ cpr. 12528

26. Peng WX, Koirala P, Mo YY. LncRNA-mediated regulation of cell signaling in cancer. Oncogene. 2017;36(41):5661-5667. doi:10.1038/ onc. 2017.184

27. Paraskevopoulou MD, Hatzigeorgiou AG. Analyzing MiRNA lncRNA interactions. Methods Mol Biol. 2016;1402:271-286.

28. Ferrè F, Colantoni A, Helmer-Citterich M. Revealing proteinlncRNA interaction. Brief Bioinform. 2016;17(1):106-116. doi:10.1093/bib/bbv031

29. Mayr C. Regulation by 3'-Untranslated Regions. Annu Rev Genet. 2017;51:171-194. doi:10.1146/annurev-genet-120116-024704

30. Qi X, Zhang DH, Wu N, Xiao JH, Wang X, Ma W. ceRNA in cancer: possible functions and clinical implications. J Med Genet. 2015;52 (10):710-718. doi:10.1136/jmedgenet-2015-103334

31. Thomson DW, Dinger ME. Endogenous microRNA sponges: evidence and controversy. Nat Rev Genet. 2016;17(5):272-283. doi:10.1038/nrg.2016.20

32. Prasad A, Sharma N, Prasad M. Noncoding but coding: pri-miRNA into the action. Trends Plant Sci. 2021;26(3):204-206. doi:10.1016/j. tplants.2020.12.004

33. Geisler S, Coller J. RNA in unexpected places: long non-coding RNA functions in diverse cellular contexts. Nat Rev Mol Cell Biol. 2013;14 (11):699-712. doi:10.1038/nrm3679 
34. Wu W, Ji X, Zhao Y. Emerging roles of long non-coding RNAs in chronic neuropathic pain. Front Neurosci. 2019;13. doi:10.3389/ fnins.2019.01097

35. Wu S, Bono J, Tao YX. Long noncoding RNA (lncRNA): a target in neuropathic pain. Expert Opin Ther Targets. 2019;23(1):15-20. doi:10.1080/14728222.2019.1550075

36. Yu B, Zhou S, Hu W, et al. Altered long noncoding RNA expressions in dorsal root ganglion after rat sciatic nerve injury. Neurosci Lett. 2013;534(1):117-122. doi:10.1016/j.neulet.2012.12.014

37. Tang S, Jing H, Huang Z, et al. Identification of key candidate genes in neuropathic pain by integrated bioinformatic analysis. $J$ Cell Biochem. 2020;121(2):1635-1648. doi:10.1002/jcb.29398

38. Hu JZ, Rong ZJ, Li M, et al. Silencing of incRNA PKIA-AS1 attenuates spinal nerve ligation-induced neuropathic pain through epigenetic downregulation of CDK6 expression. Front Cell Neurosci. 2019;13:1-12. doi:10.3389/fncel.2019.00050

39. Cao S, Yuan J, Zhang D, et al. Transcriptome changes in dorsal spinal cord of rats with neuropathic pain. J Pain Res. 2019;12:3013-3023. doi:10.2147/JPR.S219084

40. Zhou J, Fan Y, Chen H. Analyses of long non-coding RNA and mRNA profiles in the spinal cord of rats using RNA sequencing during the progression of neuropathic pain in an SNI model. RNA Biol. 2017;14(12):1810-1826. doi:10.1080/15476286.2017.1371400

41. Mao P, Li CR, Zhang SZ, Zhang Y, Liu BT, Fan BF. Transcriptomic differential lncRNA expression is involved in neuropathic pain in rat dorsal root ganglion after spared sciatic nerve injury. Braz J Med Biol Res. 2018;51(10):16-21. doi:10.1590/1414-431×20187113

42. Jiang BC, Sun WX, He LN, Cao DL, Zhang ZJ, Gao YJ. Identification of IncRNA expression profile in the spinal cord of mice following spinal nerve ligation-induced neuropathic pain. Mol Pain. 2015;11(1):1-18. doi:10.1186/s12990-015-0047-9

43. Liu Z, Liang Y, Wang H, et al. LncRNA expression in the spinal cord modulated by minocycline in a mouse model of spared nerve injury. $J$ Pain Res. 2017;10:2503-2514. doi:10.2147/JPR.S147055

44. Zhou J, Xiong Q, Chen H, Yang C, Fan Y. Identification of the spinal expression profile of non-coding RNAs involved in neuropathic pain following spared nerve injury by sequence analysis. Front Mol Neurosci. 2017;10:1-22. doi:10.3389/fnmol.2017.00091

45. Wu S, Marie Lutz B, Miao X, et al. Dorsal root ganglion transcriptome analysis following peripheral nerve injury in mice. Mol Pain. 2016;12:1-14. doi:10.1177/1744806916629048

46. He J, Wang H, Huang J, et al. Diabetic neuropathic pain induced by streptozotocin alters the expression profile of non-coding RNAs in the spinal cord of mice as determined by sequencing analysis. Exp Ther Med. 2021;22(1):1-11. doi:10.3892/etm.2021.10207

47. Li Y, Yin C, Liu B, et al. Transcriptome profiling of long noncoding RNAs and mRNAs in spinal cord of a rat model of paclitaxel-induced peripheral neuropathy identifies potential mechanisms mediating neuroinflammation and pain. $J$ Neuroinflammation. 2021;18(1):1-22. doi:10.1186/s12974-020-02040-8

48. Wang LX, Wang ZJ. Animal and cellular models of chronic pain. $A d v$ Drug Deliv Rev. 2003;55(8):949-965. doi:10.1016/S0169-409X(03) 00098-X

49. Jaggi AS, Jain V, Singh N. Animal models of neuropathic pain. Fundam Clin Pharmacol. 2011;25(1):1-28. doi:10.1111/j.14728206.2009.00801.x

50. Cichon J, Sun L, Yang G. Spared nerve injury model of neuropathic pain in mice. Bio-Protocol. 2018;8(6). doi:10.21769/BioProtoc.2777

51. Zhao X, Tang Z, Zhang H, et al. A long noncoding RNA contributes to neuropathic pain by silencing Kcna2 in primary afferent neurons. Nat Neurosci. 2013;16(8):1024-1031. doi:10.1038/nn.3438

52. Iwasaki H, Sakai A, Maruyama M, Ito T, Sakamoto A, Suzuki H. Increased H19 long non-coding RNA expression in Schwann cells in peripheral neuropathic pain. J Nippon Med Sch. 2019;86(4):215-221. doi:10.1272/jnms.JNMS.2018_86-402
53. Zhang Z, Sun X, Zhao G, Ma Y, Zeng G. LncRNA embryonic stem cells expressed 1 (Lncenc1) is identified as a novel regulator in neuropathic pain by interacting with EZH2 and downregulating the expression of Bai1 in mouse microglia. Exp Cell Res. 2021;399 (1):112435. doi:10.1016/j.yexcr.2020.112435

54. Wang L, Zhu K, Yang B, Cai Y. Knockdown of Linc00052 alleviated spinal nerve ligation-triggered neuropathic pain through regulating miR-448 and JAK1. J Cell Physiol. 2020;235(10):6528-6535. doi: $10.1002 /$ jcp. 29465

55. Liu Y, Sun H, Sun Y. LncRNA p21, downregulating miR-181b, aggravates neuropathic pain by upregulating Tnfaip1 and inhibit the AKT/CREB axis. Brain Res Bull. 2021;171:150-161. doi:10.1016/j. brainresbull.2021.03.005

56. Zhang JY, Lv DB, Su YN, et al. LncRNA SNHG1 attenuates neuropathic pain following spinal cord injury by regulating CDK4 level. Eur Rev Med Pharmacol Sci. 2020;24(23):12034-12040. doi:10.26355/eurrev_202012_23992

57. Pan X, Shen C, Huang Y, Wang L, Xia Z. Erratum: Loss of SNHG4 attenuated spinal nerve ligation-triggered neuropathic pain through sponging miR-423-5p. Mediators Inflamm. 2020;2020:2094948. Mediators Inflamm. 2020;2020. doi:10.1155/2020/2094948

58. Chen M, Yang Y, Zhang W, et al. Long noncoding RNA SNHG5 knockdown alleviates neuropathic pain by targeting the miR-154-5p/ CXCL13 axis. Neurochem Res. 2020;45(7):1566-1575. doi:10.1007/ s11064-020-03021-2

59. Wei M, Li L, Zhang Y, Zhang ZJ, Liu HL, Bao HG. LncRNA X inactive specific transcript contributes to neuropathic pain development by sponging miR-154-5p via inducing toll-like receptor 5 in CCI rat models. $J$ Cell Biochem. 2019;120(2):1271-1281. doi: $10.1002 / \mathrm{jcb} .27088$

60. Jin H, Du XJ, Zhao Y, Xia DL. XIST/miR-544 axis induces neuropathic pain by activating STAT3 in a rat model. $J$ Cell Physiol. 2018;233(8):5847-5855. doi:10.1002/jcp.26376

61. Yan XT, Lu JM, Wang Y, et al. XIST accelerates neuropathic pain progression through regulation of miR-150 and ZEB1 in CCI rat models. J Cell Physiol. 2018;233(8):6098-6106. doi:10.1002/ jcp. 26453

62. Zhao Y, Li S, Xia N, Shi Y, Zhao CM. Effects of XIST/miR-137 axis on neuropathic pain by targeting TNFAIP1 in a rat model. $J$ Cell Physiol. 2018;233(5):4307-4316. doi:10.1002/jcp.26254

63. Tian X, Xu G. Clinical value of lncRNA MALAT1 as a prognostic marker in human cancer: systematic review and meta-analysis. $B M J$ Open. 2015;5(9):e008653. doi:10.1136/bmjopen-2015-008653

64. Zhao Y, Yu YQ, You S, et al. Long non-coding RNA MALAT1 as a detection and diagnostic molecular marker in various human cancers: a pooled analysis based on 3255 subjects. Onco Targets Ther. 2020;13:5807-5817. doi:10.2147/OTT.S250796

65. Wu J, Wang C, Ding H. LncRNA MALAT1 promotes neuropathic pain progression through the miR-154-5p/AQP9 axis in CCI rat models. Mol Med Rep. 2020;21(1):291-303. doi:10.3892/ mmr.2019.10829

66. Ma X, Wang H, Song T, Wang W, Zhang Z. IncRNA MALAT1 contributes to neuropathic pain development through regulating miR-129-5p/HMGB1 axis in a rat model of chronic constriction injury. Int $J$ Neurosci. 2020;130(12):1215-1224. doi:10.1080/ 00207454.2020.1731508

67. Chen ZL, Liu JY, Wang F, Jing X. Suppression of MALAT1 ameliorates chronic constriction injury-induced neuropathic pain in rats via modulating miR-206 and ZEB2. J Cell Physiol. 2019;234(9):1564715653. doi: $10.1002 /$ jcp. 28213

68. Wang W, Min L, Qiu X, et al. Biological function of long non-coding RNA (LncRNA) Xist. Front Cell Dev Biol. 2021;9:1-27.

69. Zhang D, Mou JY, Wang F, Liu J, Hu X. CRNDE enhances neuropathic pain via modulating miR-136/IL6R axis in CCI rat models. $J$ Cell Physiol. 2019;234(12):22234-22241. doi:10.1002/jcp.28790 
70. Peng C, Zhang C, Su Z, Lin D. DGCR5 attenuates neuropathic pain through sponging miR-330-3p and regulating PDCD4 in CCI rat models. J Cell Physiol. 2019;234(5):7292-7300. doi:10.1002/ jcp. 27487

71. Wen Y, Fan X, Bu H, et al. Downregulation of lncRNA FIRRE relieved the neuropathic pain of female mice by suppressing HMGB1 expression. Mol Cell Biochem. 2021;476(2):841-852. doi:10.1007/s11010-020-03949-7

72. Tian Y, Sun L, Qi T. Long noncoding RNA gas5 ameliorates chronic constriction injury induced neuropathic pain in rats by modulation of the mir-452-5p/celf2 axis. Can J Physiol Pharmacol. 2020;98 (12):870-877. doi:10.1139/cjpp-2020-0036

73. Shen F, Zheng H, Zhou L, Li W, Zhang Y, Xu X. LINC00657 expedites neuropathic pain development by modulating miR-136/ ZEB1 axis in a rat model. $J$ Cell Biochem. 2019;120(1):1000-1010. doi: $10.1002 /$ jcb. 27466

74. Xia LX, Ke C, Lu JM. NEAT1 contributes to neuropathic pain development through targeting miR-381/HMGB1 axis in CCI rat models. J Cell Physiol. 2018;233(9):7103-7111. doi:10.1002/ jcp. 26526

75. Li Z, Li A, Yan L, Yang T, Xu W, Fan P. Downregulation of long noncoding RNA DLEU1 attenuates hypersensitivity in chronic constriction injury-induced neuropathic pain in rats by targeting miR133a-3p/SRPK1 axis. Mol Med. 2020;26(1). doi:10.1186/s10020020-00235-6

76. Li K, Jiao Y, Ren X, You D, Cao R. Long noncoding RNA h19 induces neuropathic pain by upregulating cyclin-dependent kinase 5mediated phosphorylation of camp response element binding protein. J Pain Res. 2020;13:2113-2124. doi:10.2147/JPR.S240273

77. Li G, Jiang H, Zheng C, et al. Long noncoding RNA MRAK009713 is a novel regulator of neuropathic pain in rats. Pain. 2017;158 (10):2042-2052. doi:10.1097/j.pain.0000000000001013

78. Li H, Fan L, Zhang Y, Cao Y, Liu X. SNHG16 aggravates chronic constriction injury-induced neuropathic pain in rats via binding with miR-124-3p and miR-141-3p to upregulate JAG1. Brain Res Bull. 2020;165:228-237. doi:10.1016/j.brainresbull.2020.09.025

79. Zhang C, Peng Y, Wang Y, Xu H, Zhou X. Transcribed ultraconserved noncoding RNA uc. 153 is a new player in neuropathic pain. Pain. 2020;161(8):1744-1754. doi:10.1097/j.pain.0000000000001868

80. Zhang Q, Zhu D, Li Q. LncRNA CRNDE exacerbates neuropathic pain in chronic constriction injury-induced(CCI) rats through regulating miR-146a-5p/WNT5A pathway. Bioengineered. 2021;12 (1):7348-7359. doi:10.1080/21655979.2021.1972901

81. Callaghan BC, Cheng HT, Stables CL, Smith AL, Feldman EL. Diabetic neuropathy: clinical manifestations and current treatments. Lancet Neurol. 2012;11(6):521-534. doi:10.1016/S1474-4422(12) 70065-0

82. Feldman EL, Nave KA, Jensen TS, Bennett DLH. New horizons in diabetic neuropathy: mechanisms, bioenergetics, and pain. Neuron. 2017;93(6):1296-1313. doi:10.1016/j.neuron.2017.02.005

83. Liu C, Li C, Deng Z, Du E, Xu C. Long non-coding RNA BC168687 is involved in TRPV1-mediated diabetic neuropathic pain in rats. Neuroscience. $\quad 2018 ; 374: 214-222$ doi:10.1016/j. neuroscience.2018.01.049

84. Liu C, Tao J, Wu H, et al. Effects of LncRNA BC168687 siRNA on diabetic neuropathic pain mediated by $\mathrm{P} 2 \mathrm{X} 7$ receptor on SGCs in DRG of rats. Biomed Res Int. 2017;2017:1-10. doi:10.1155/2017/ 7831251
85. Peng H, Zou L, Xie J, et al. IncRNA NONRATT021972 siRNA decreases diabetic neuropathic pain mediated by the $\mathrm{P} 2 \mathrm{X} 3$ receptor in Dorsal root Ganglia. Mol Neurobiol. 2017;54(1):511-523. doi:10.1007/s12035-015-9632-1

86. Liu S, Zou L, Xie J, et al. LncRNA NONRATT021972 siRNA regulates neuropathic pain behaviors in type 2 diabetic rats through the P2X7 receptor in dorsal root ganglia. Mol Brain. 2016;9(1):1-13. doi:10.1186/s13041-016-0226-2

87. Wang S, Xu H, Zou L, et al. LncRNA uc.48+ is involved in diabetic neuropathic pain mediated by the $\mathrm{P} 2 \mathrm{X} 3$ receptor in the dorsal root ganglia. Purinergic Signal. 2016;12(1):139-148. doi:10.1007/ s11302-015-9488-x

88. Xiong W, Huang L, Shen Y, et al. Effects of lncRNAuc.48+ siRNA on the release of CGRP in the spinal cords of rats with diabetic neuropathic pain. Int J Clin Exp Pathol. 2017;10(9):9960-9969.

89. Cai J, Yan Y, Zhang D, et al. Silencing of lncRNA Gm14461 alleviates pain in trigeminal neuralgia through inhibiting astrocyte activation. IUBMB Life. 2020;72(12):2663-2671. doi:10.1002/ iub. 2395

90. Xu M, Yan Y, Zhu M, Wang Z, Zhang X, Zhang D. Effects of long non-coding RNA Gm14461 on pain transmission in trigeminal neuralgia. J Inflamm. 2020;17(1):1-7.

91. Xiong W, Tan M, Tong Z, et al. Effects of long non-coding RNA uc. $48+$ on pain transmission in trigeminal neuralgia. Brain Res Bull. 2019;147:92-100. doi:10.1016/j.brainresbull.2019.02.009

92. Meng C, Yang X, Liu Y, et al. Decreased expression of IncRNA Malat1 in rat spinal cord contributes to neuropathic pain by increasing neuron excitability after brachial plexus avulsion. J Pain Res. 2019;12:1297-1310. doi:10.2147/JPR.S195117

93. Liu LP, Zhang J, Pu B, Li WQ, Wang YS. Upregulation of JHDM1DAS1 alleviates neuroinflammation and neuronal injury via targeting miR-101-3p-DUSP1 in spinal cord after brachial plexus injury. Int Immunopharmacol. 2020;89(374):106962. doi:10.1016/j.intimp. 2020.106962

94. Sun RM, Wei J, Wang SS, Xu GY, Jiang GQ. Upregulation of lncRNA-NONRATT021203.2 in the dorsal root ganglion contributes to cancer-induced pain via CXCL9 in rats. Biochem Biophys Res Commun. 2020;524(4):983-989. doi:10.1016/j.bbrc.2020.01.163

95. Kong C, Du J, Bu H, Huang C, Xu F, Ren H. LncRNA KCNA2-AS regulates spinal astrocyte activation through STAT3 to affect postherpetic neuralgia. Mol Med. 2020;26(1). doi:10.1186/s10020-02000232-9

96. Xian S, Ding R, Li M, Chen F. LncRNA NEAT1/miR-128-3p/AQP4 axis regulating spinal cord injury-induced neuropathic pain progression. $J$ Neuroimmunol. 2021;351(169):577457. doi:10.1016/j. jneuroim.2020.577457

97. Zhang P, Sun H, Ji Z. Downregulating lncRNA PVT1 relieves astrocyte overactivation induced neuropathic pain through targeting miR186-5p/CXCL13/CXCR5 axis. Neurochem Res. 2021;46(6):14571469.

98. Zhang L, Feng H, Jin Y, et al. Long non-coding RNA LINC01119 promotes neuropathic pain by stabilizing BDNF transcript. Front Mol Neurosci. 2021;14:1-13. doi:10.3389/fnmol.2021.673669

99. Mapplebeck JCS, Beggs S, Salter MW. Review articles from the 5th International Meeting of the IASP Special Interest Group on Neuropathic Pain (NeuPSIG) Sex differences in pain: a tale of two immune cells. Pain. 2015;157:2-6. 
Journal of Pain Research

Dovepress

\section{Publish your work in this journal}

The Journal of Pain Research is an international, peer reviewed, open access, online journal that welcomes laboratory and clinical findings in the fields of pain research and the prevention and management of pain. Original research, reviews, symposium reports, hypothesis formation and commentaries are all considered for publication. The manuscript management system is completely online and includes a very quick and fair peer-review system, which is all easy to use. Visit http:// www.dovepress.com/testimonials.php to read real quotes from published authors.

Submit your manuscript here: https://www.dovepress.com/journal-of-pain-research-journal 